\title{
Floodplain forest communities along the Mura River (NE Slovenia)
}

\author{
Petra KoŠIR ${ }^{1,2, *}$, ANDraž ČARni ${ }^{1,3}$, AleKSANDER MARINŠEK $^{1}$, Urban ŠIlC $^{1}$ \\ ${ }^{1}$ Jovan Hadži Institute of Biology, Research Centre of the Slovenian Academy of \\ Sciences and Arts, Novi trg 2, SI-1001 Ljubljana, Slovenia \\ ${ }^{2}$ University of Primorska, UP FAMNIT, Glagoljaška 8, SI-6000 Koper, Slovenia \\ ${ }^{3}$ University of Nova Gorica, Nova Gorica, Slovenia
}

\begin{abstract}
Ecological gradients along river banks of the Mura River influence forest species composition. On the basis of 58 relevés of floodplain forests along the Mura River, the classification of vegetation plots was performed with the Pc-Ord program. The diagnostic species combination for three clusters revealed after classification was calculated by fidelity measure (phi-coefficient) and presented in an analytic table. Average Ellenberg inidicator values, stream distances and relative elevations of the relevés were passively projected onto PCA to show ecological relationships among them. Correlations of plant functional type and stream distance gradients were calculated with regression analysis. For the main edifiers response curves to the stream distance gradients were made. The classification of the Mura floodplain forests has revealed three ecologically interpretable vegetation types: Salicetum albae (most humid and nutrient-rich sites), Fraxino-Ulmetum allietosum ursini (ecologically intermediate sites), F.-U. quercetosum robori (the driest and the least nutrient-rich sites). Zonation of vegetation is connected to distance from the closest stream which influences species distribution through ecological gradients of moisture and nutrient. The proportion of therophytes is significantly negatively correlated with the distance from the closest stream and the proportion of neophytes is significantly negatively correlated with distance from the main stream.
\end{abstract}

Key words: Floodplain, gradient, hardwood, neophytes, riparian, vegetation, softwood, zonation, Mura River

Abbreviations: DCS - distance from the closest stream, DMS - distance from the main stream.

\section{Introduction}

Floodplain forests are subject to periodic over/the-bank flooding and cycles of erosion and deposition of nutrient-rich sediment. Well drained and nutrient-rich soils of floodplain

* Corresponding author, e-mail: petrako@zrc-sazu.si

Copyright ${ }^{\circledR} 2013$ by Acta Botanica Croatica, the Faculty of Science, University of Zagreb. All rights reserved. 
forests distinguish these forests from the floodplain swamp forests on stagnant water sites with gleyic soils, which are periodically flooded predominately by ground water. Floodplain forests are characterized by the highest species richness and diversity, density and productivity (Deiller et al. 2001, Mitsch and GosselinK 2000, Schnitzler 1994). They include several microhabitats harbouring numerous plant and invertebrate species unable to survive elsewhere (MACHAR 2001). Therefore floodplain forests, according to the Habitat Directive, belong among the habitats of the greatest importance for nature protection on the European scale.

Historically, natural floodplain forests have been fragmented and heavily impacted by watercourse regulations, timber harvesting and other human activities (KLIMO and HAGER 2001).

Like other large European rivers, the Mura has undergone several hydraulic management phases since the $19^{\text {th }}$ century. These regulation works and other human impacts, such as plantation and felling, have modified the floodplain forest ecosystem. Therefore identification of vegetation types along the Mura River is very difficult, undistinct and has not been done yet. Despite many an intervention into the river and its current, the Mura has still preserved so many natural treasures that it is treated as a nationally important value (GORŠAK and BAKAN 2003).

Flooded forests have already been thoroughly studied in many parts of Europe (MÜLLER 1992, SCHNitZler 1994, VichereK et al. 2000, PAAL et al. 2007, WiLlNER and GrABHERR 2007, KeVEy 2008, KLIMo et al. 2008, PoLDINI et al. 2011) and also in the southeastern part of Europe in the area of large rivers, such as the Sava, Drava and Danube (HoRvat et al. 1974, VuKELIĆ and BARIČEVIĆ 2004, 2005).

Two types of forests have usually been identified in the area of floodplain forests: softwood and hardwood forests. Softwood forests are mainly composed of early successional and light-demanding species such as Salix alba, Salix fragilis, Populus nigra and Populus alba. Hardwood forests are dominated by long-living species, with Fraxinus excelsior/Fraxinus angustifolia, Quercus robur and Ulmus minor/Ulmus laevis. Alluvial hardwood forests are found on flooded but well-drained and fertile soils of large European floodplain (SCHNITZLER 1994)

In Slovenia there were some surveys of vegetation of river banks, about all white willow stands Salicetum albae, along some other rivers, such as the Drava (PETRINEC 1999), Soča (DAKSKOBLER et al. 2004), Krka and Mirna (ŠILC 2003), mostly with a relatively narrow belt of riverine forest vegetation. The Mura River has the best preserved floodplain in Slovenia, but floodplain forests of river banks of the Mura River remain so far unresearched.

The main research questions of the study were:

- Which are the main forest vegetation types on the banks of the Mura River and the main ecological gradients that influence species composition of these forests?

- Despite the big changes in flooding regime and human impact (plantation, cutting down) does zonation of vegetation along the Mura River still exist? Is zonation connected to distance from the main stream of the river (DMS) or distance from the closest stream (DCS)?

- What is the distribution of plant functional types (life forms, plant ecological strategies, origin and residence time status) along stream distance gradient? 


\section{Material and methods}

\section{Study area}

The study took place along the Mura River in the eastern part of Slovenia, on the banks of the Mura River and Holocene terraces. This part of Slovenia has a continental climate: the annual mean precipitation is $800 \mathrm{~mm}$ and annual mean temperature is $9.2{ }^{\circ} \mathrm{C}$.

The study area belongs to the sub-Pannonian region, as we can find some Pannonian features; flooded and swamp forests, some very rare Pannonian elements. Since the area is composed mainly of sandstone, the flora shows a mainly central European floristic character.

The Mura (Mur) river is a Central European river, springing at $1898 \mathrm{~m}$ a.s.l. in the Eastern Alps in Austria. The Mura River is the largest tributary of the Drava river, that is the fourth largest tributary of the Danube River. When reaching Slovenia, the Mura river forms a 34-km long state border line between Austria and Slovenia, flows through Slovenian territory for $29 \mathrm{~km}$ and then becomes a state border again: first between Slovenia and Croatia (33 km), and then between Croatia and Hungary (GLOBEVNIK and Mikoš 2009). In Slovenia it has riverbed in lowland with a small gradient. The level of the Mura River increases in spring because of the melting snow in the high mountains and in autumn because of higher precipitation.

Regulation works on the Mura River started in $19^{\text {th }}$ century. Before regulation, $40 \%$ of water flowed through main channel, but today almost all the water flows in the main channel. There are still some side channels in the forests along the Mura River with connection to the main stream of the Mura. Flood protection dikes were constructed in the 1972-1990 period using a 100 year flood design to protect cultivated areas. The Mura River corridor between the dikes is up to $1 \mathrm{~km}$ wide (GLOBEVNIK and MiKoš 2009). Most of the forests range inside these dikes.

\section{Sampling and measurements}

Vegetation of floodplain forests was investigated according to the standard Central European method (BRAUN-BLANQUET 1964). We made 58 relevés of floodplain forests along the Mura River. All the relevés were made inside levees in the area of periodic floods. We did not include floodplain swamp forests (class Alnetea glutinosae) in our research as they have already been investigated (ACCETTO 1994, NEMESSZEGHY 1986, GlaVAĆ 1975). For each plot, GPS coordinates were collected and later on, distances from main stream of Mura (DMS) and distances from the closest stream (DCS), which may be the main or a side stream, were measured from the map in Arc-Gis program. In 14\% of relevés (8 of 58) DCS value equalled DMS value. This means that in $86 \%$ of the relevés the closest stream was a side stream. We also measured the relative elevation of each plot (elevation relative to average river level) with DMR of the area as it is known that elevation as well as distance from the river affects hydroperiod (flood frequency and duration) and thus influences species distribution and abundance (TURNER et al. 2004).

\section{Data analysis}

58 relevés made on flooded sites of the Mura River were entered into the TURBOvEG (HENNEKENS and SCHAMINÉE 2001) database. 
The numerical classification of vegetation plots, based on their species composition, was performed with PC-ORD 5.0 program (MCCunE and MEFFORD 2005). The data was square root transformed. Euclidean (Pythagorean) distance as the distance measure and Flexible Beta method for group linkage were used. We made several classifications with different numbers of clusters of relevés. We subjectively accepted classification with three clusters being most ecologically sound.

58 relevés are presented in the analytic table. The nomenclature of taxa is according to Flora Europaea (TuTiN et al. 1964-1980). Diagnostic species for the clusters (corresponding associations and subassociations) were determined in the JUICE program (TICHÝ 2002) by their fidelity values. Fidelity was calculated using the phi coefficient, applied to the classified data set with cluster sizes equalized to $1 / 3$ or $1 / 2$ respectively (in the case of searching for species diagnostic for two clusters together) of the size of the entire data set, of the total data set size according to TICHÝ and CHYTRÝ (2006). Species with phi $>30$ were considered as diagnostic for individual clusters, but species whose occurrence concentration in the plots of a particular cluster was not significant at $\mathrm{p}<0.05$ (Fisher's exact test) were excluded.

Unweighted average Ellenberg indicator values of relevés made on flooded sites, distances of the relevés from the streams (DMS, DCS) and relative elevation were passively projected onto a Principal Components Analysis biplot (PCA from CANOCO 4.5; TER BRAAK and ŠMILAUER 2002) to show ecological relationship among these relevés and to explain environmental gradients underlying the main ordination axes. Square root transformed cover data were used as the input data.

For further interpretation of the three clusters of flooded forests of the Mura River, unweighted average Ellenberg indicator values of 3 clusters of flooded forests, moisture and nutrient, which indicate the biggest correlations with axis 1 of the PC-ORD diagram, calculated in the JUICE program, and stream distances (DMS, DCS) were presented with Box-whiskers diagrams made in STATISTICA program (STATSOFT 2007). Boxes present mean and standard errors (SE), whiskers indicate standard deviations (SD).

Correlations of plant ecological strategies, life forms and origin and residence time status (native, archaeophyte, neophyte) and stream distance gradient were calculated with regression analysis, also in STATISTICA program. Each of the patterns was fitted with a linear regression model. The plant ecological strategies, life forms and plant status have been defined using the BIOLFLOR database (KLOTZ et al. 2002), that considers Grime's classification (GRIME 1979).

For the five most important tree species of the forests in the area, responses to the environmental variables (DCS, DMS) were fitted using the Huisman-Olff-Fresco models (HOF; HuIsman et al. 1993). HOF is a hierarchical set of five species response models with increasing complexity: model I-flat with no response, II-monotonously increasing or decreasing, III-monotonously increasing or decreasing with a »plateau«, IV-symmetric unimodal and $\mathrm{V}$-asymmetric unimodal response. Four parameters of these models were estimated using a non-linear maximum likelihood estimation procedure (OKSANEN and MiNCHIN 2002), available in Jari Oksanen's »gravy « library (http://cc.oulu.fi/\%7Ejraioksa/ softhelp/softalist.html) for the R program (http://www.r-project.org). This routine was run externally with R program (http://www.r-project.org) from the JUICE program (TICHÝ 2002), using a procedure developed by ZELENÝ and TICHÝ (2007) 


\section{Results}

The classification of the flooded forests of the Mura River is presented in the dendrogram (Fig. 1), and in the analytic table (Tab. 1). Classification into three clusters was accepted as it represents three ecologically interpretable vegetation types; 1. Salix alba and Populus nigra stands, 2. Fraxinus angustifolia subsp. oxycarpa stands and 3. Quercus robur and Carpinus betulus stands. The three clusters correspond to three communities; Salicetum albae Issler 1926, Fraxino-Ulmetum effusae Slavnić 1952 allietosum ursini subass. nova hoc loco, Fraxino-Ulmetum effusae Slavnić 1952 quercetosum robori subass. nova hoc loco.

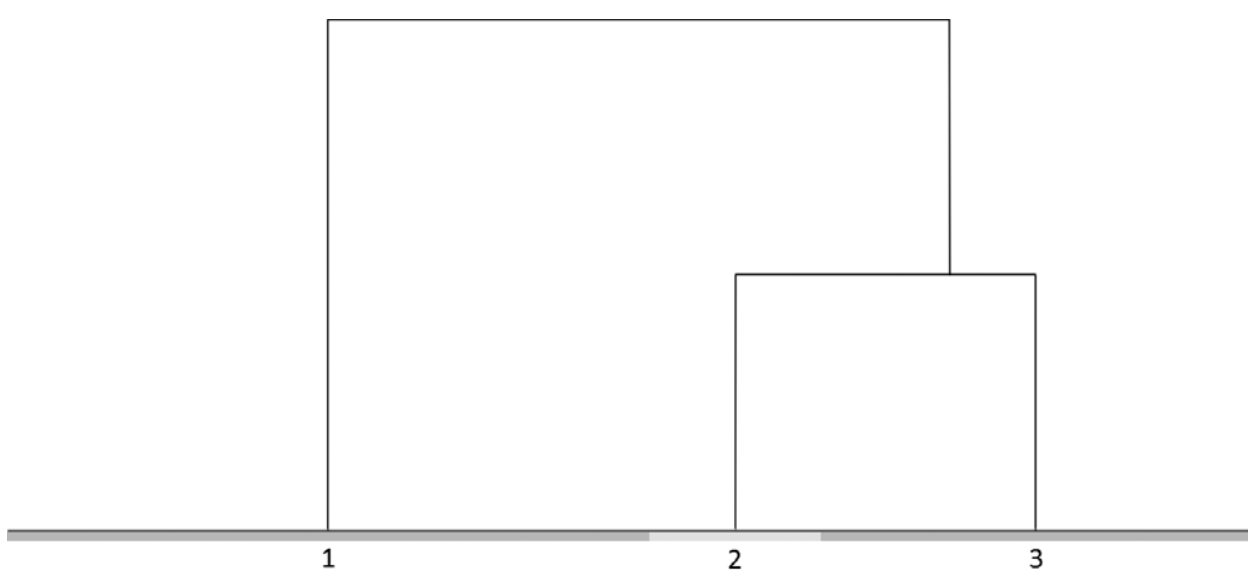

Fig. 1. Dendrogram of classification. Cluster 1: Salix alba and Populus nigra stands, cluster 2: Fraxinus angustifolia subsp. oxycarpa stands and cluster 3: Quercus robur and Carpinus betulus stands. For simplicity, the bottom part is not shown.

PCA is presented of the 58 relevés of flooded sites of the Mura River with Ellenberg indicator values (Fig. 2). Eigenvalues of the first two axes are 0.161 and 0.114 . The three communities (three clusters) thrive along a moisture and nutrient gradient. Moisture and nutrient indicator values are negatively correlated with DCS (with moisture -0.308 , with nutrients -0.341) and DMS (with moisture -0.224 , with nutrients -0.209 ). The association Salicetum albae (cluster one) occurs on the most moist and nutrient-rich sites, the subassociation Fraxino-Ulmetum effusae quercetosum robori (cluster three), on the other hand, occurs on the least moist and the least nutrient-rich sites (Fig 2, Fig. 3).

DCS is the lowest in cluster one (Salicetum albae) and the highest in cluster three (Fraxino-Ulmetum effusae quercetosum robori). DMS is also the highest in cluster three and lower in clusters one and two (Fraxino-Ulmetum effusae allietosum ursini). Cluster three shows the highest range of DMS indicating that the main stream of the Mura has the lowest effect on the distribution of Quercus robur stands, which can be also found relatively far (up to $3080 \mathrm{~m}$ far) from the main stream of Mura.

The proportion of neophytes is strongly significantly negatively correlated with DMS (Fig. 5), and not significantly correlated with DCS. The most abundant neophytes in our relevés are Robinia pseudacacia, Impatiens glandulifera, Solidago gigantea and Rudbeckia laciniata. 
KoŠIR P., ČARNI A., MARINŠEK A., ŠILC U.

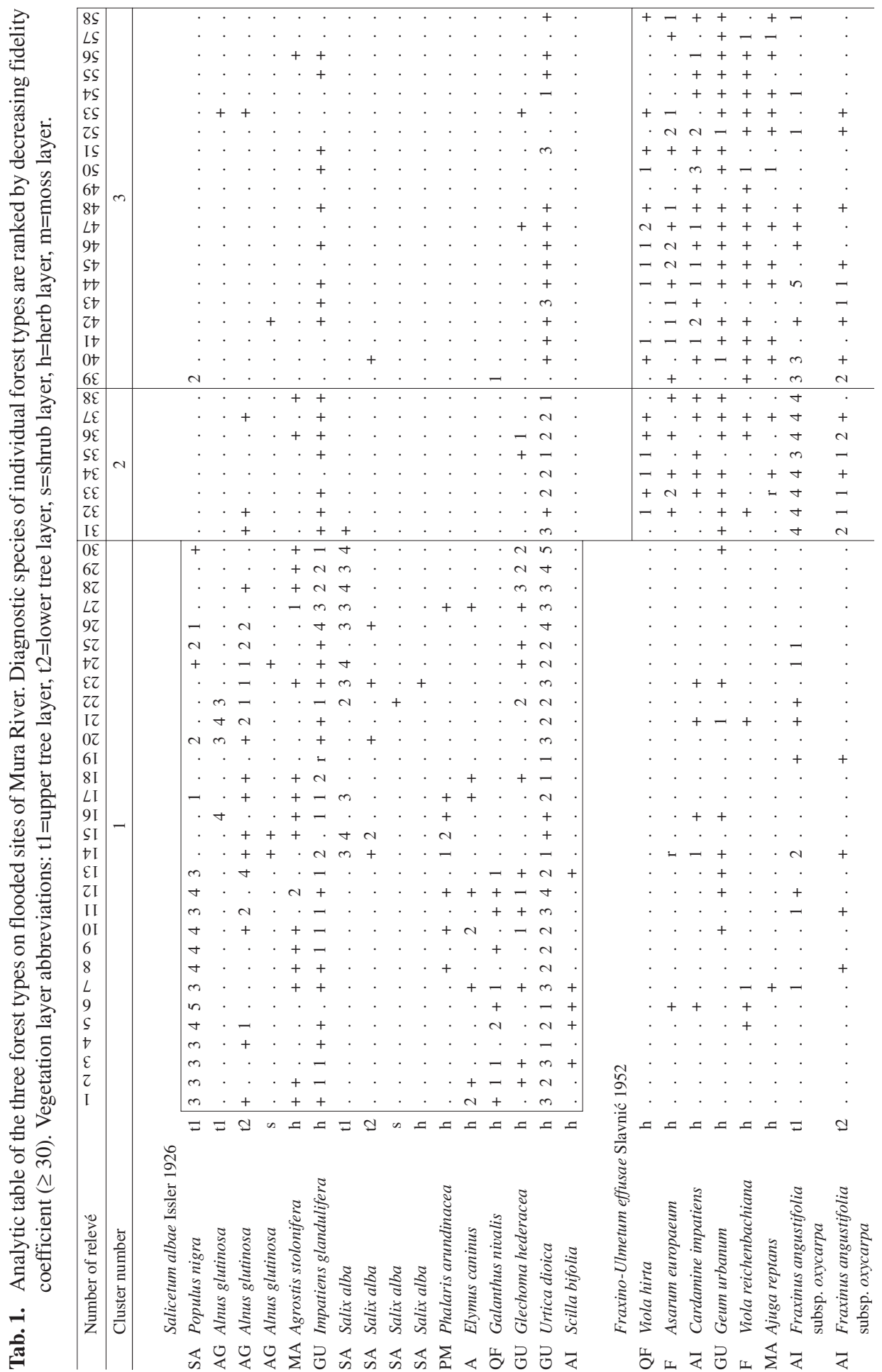




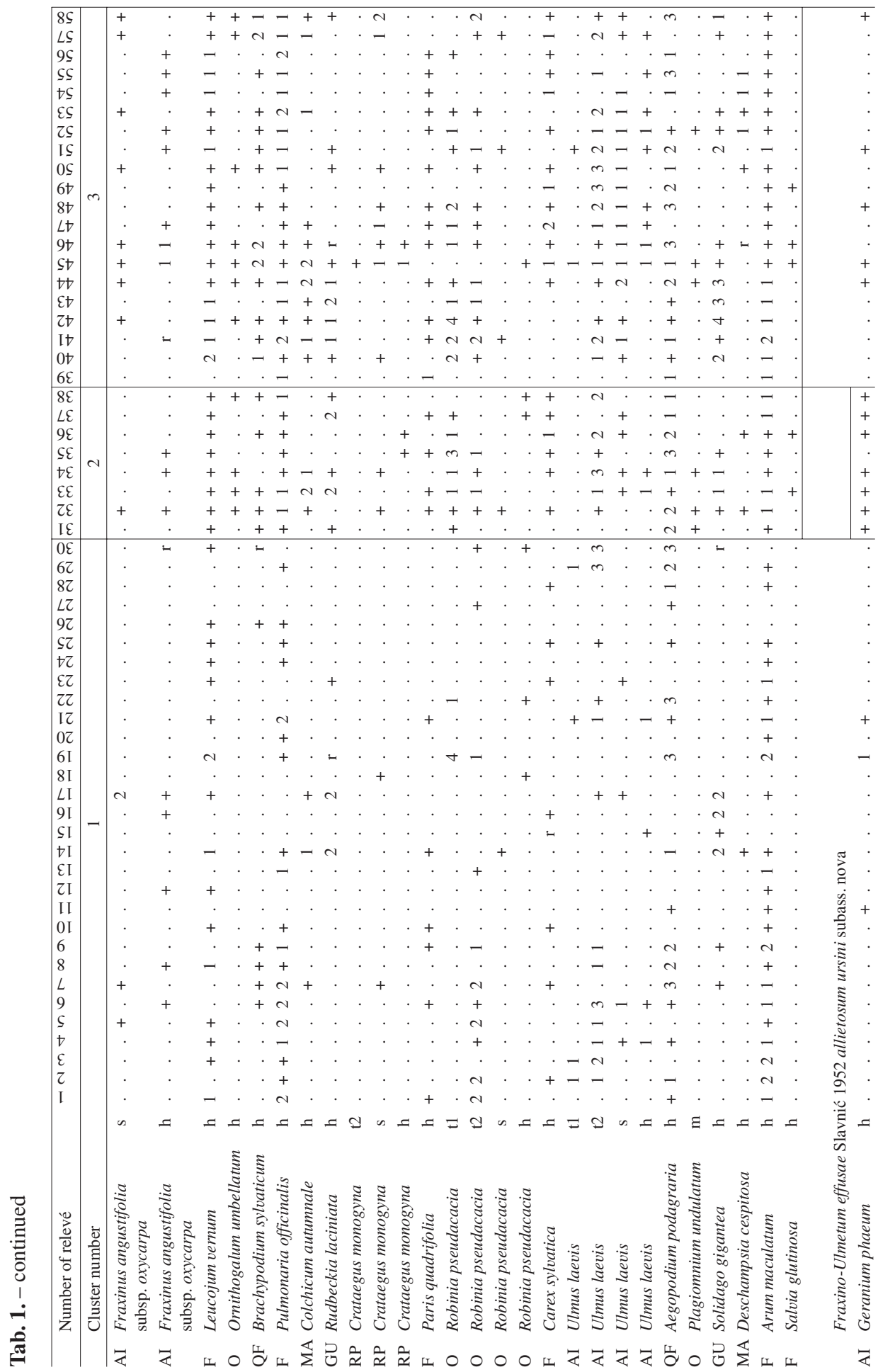


KoŠIR P., ČARNI A., MARINŠEK A., ŠILC U.

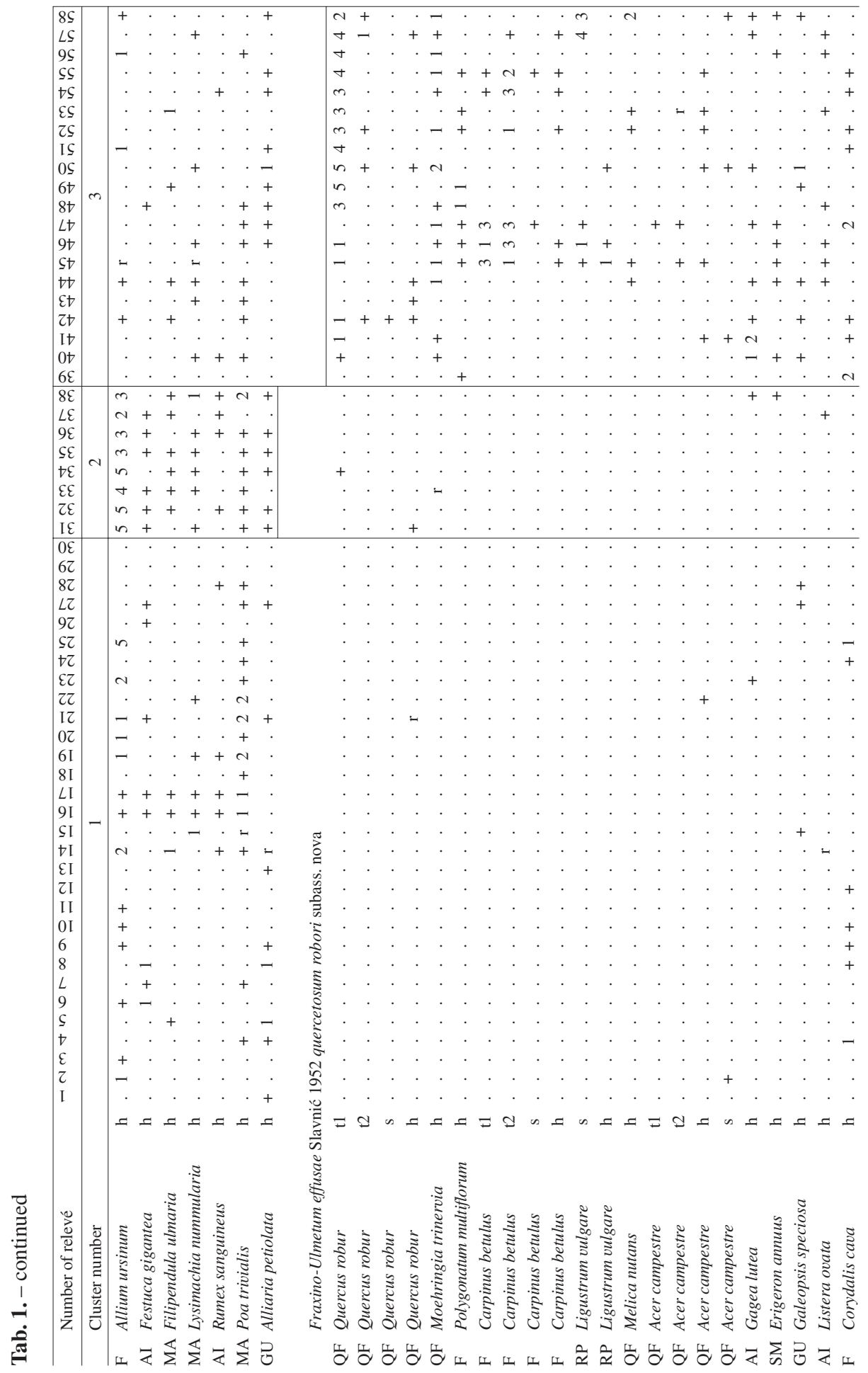




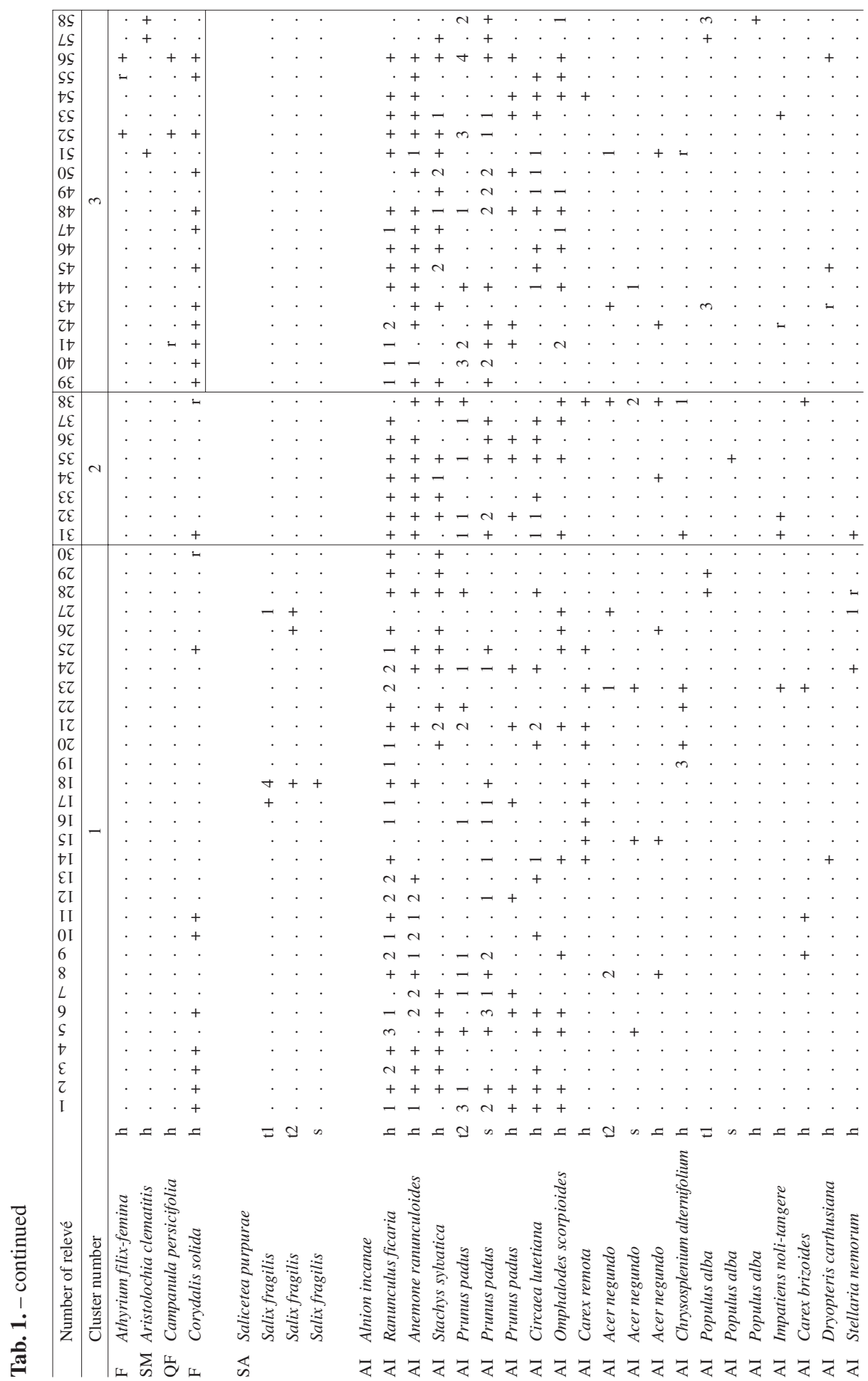


KoŠIR P., ČARNI A., MARINŠEK A., ŠILC U.

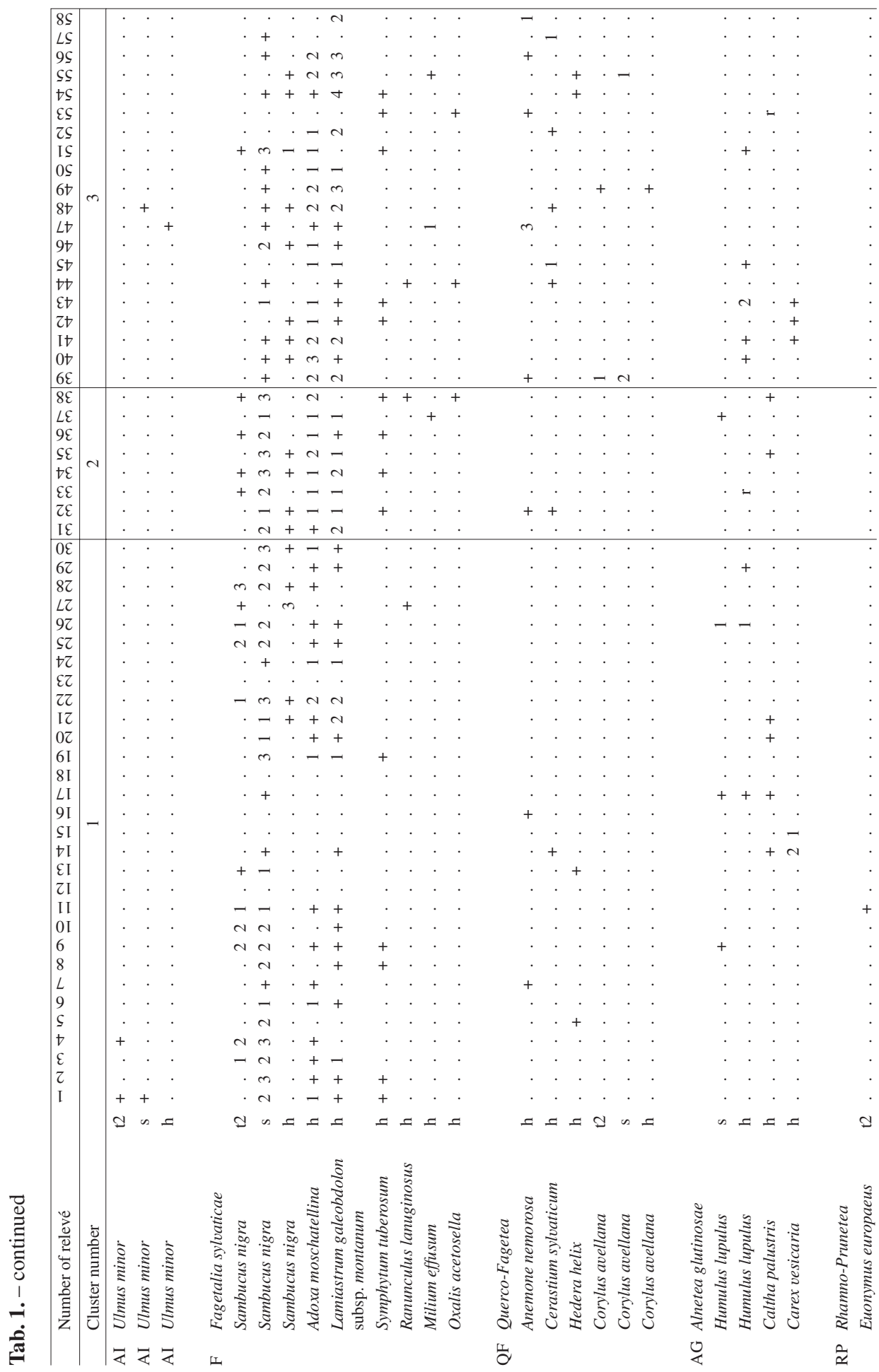




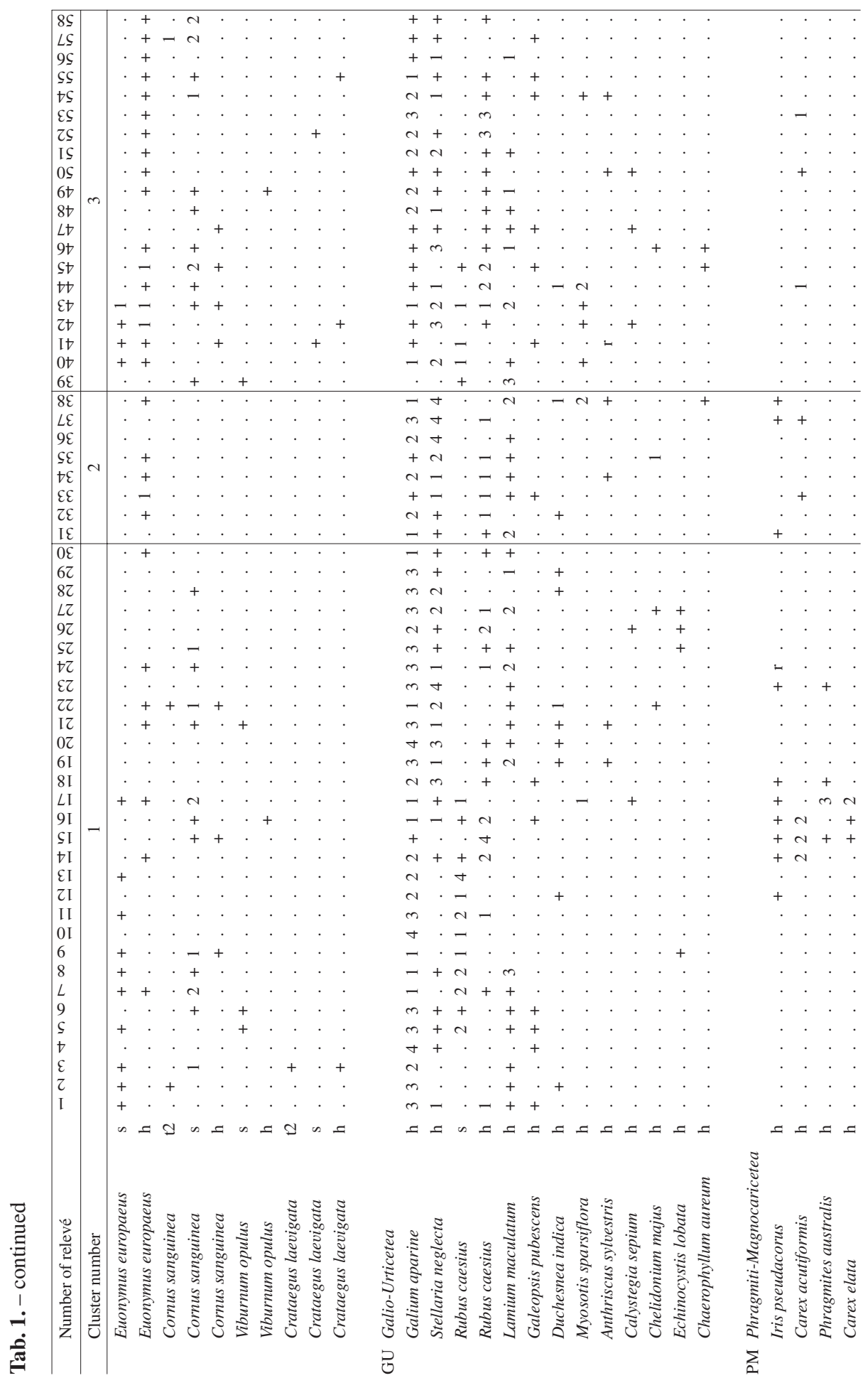


KoŠIR P., ČARNI A., MARINŠEK A., ŠILC U.

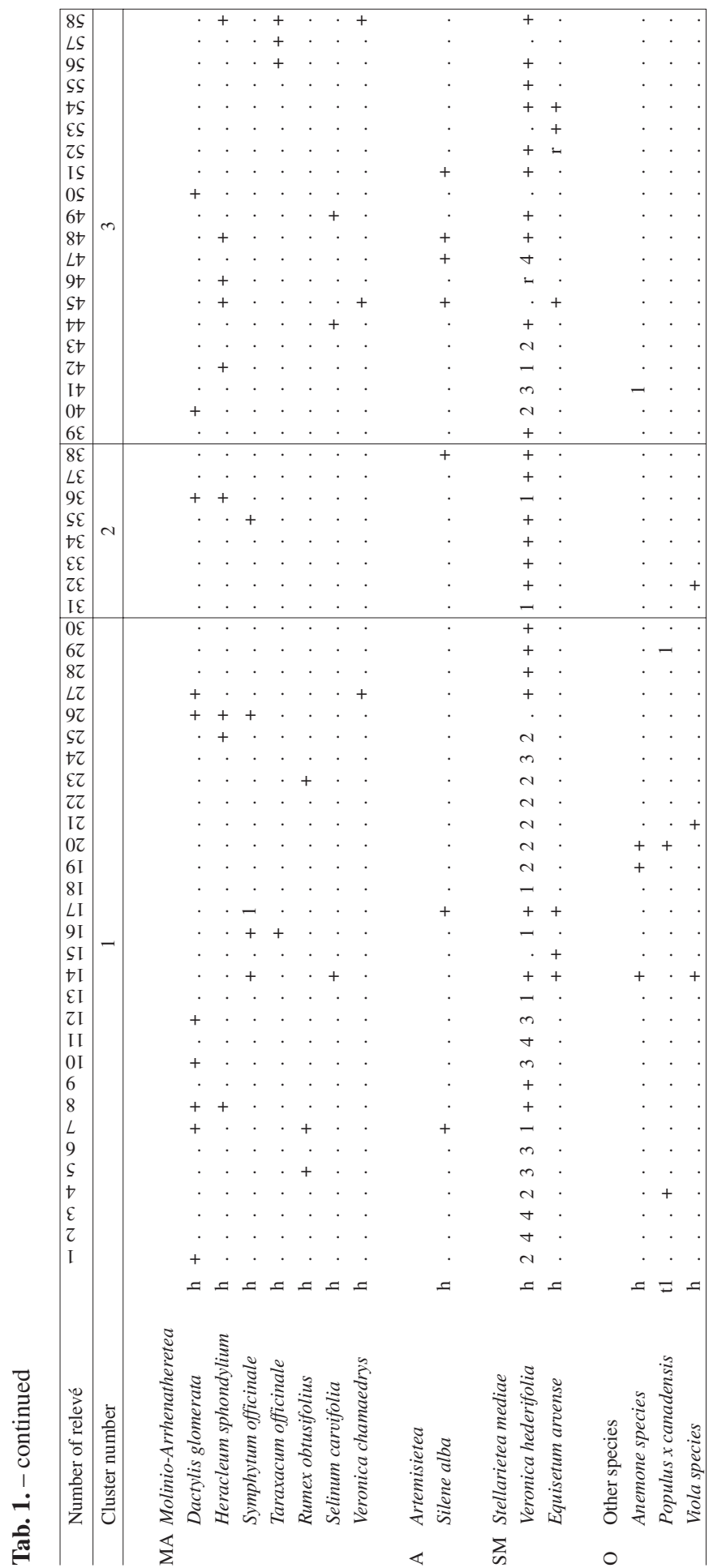

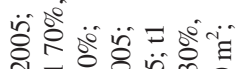

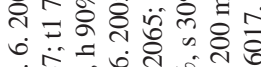

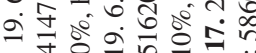

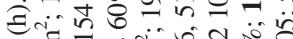

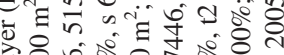

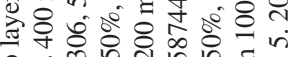

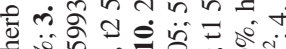

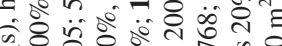

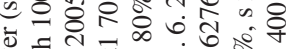

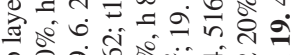

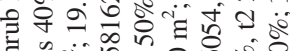
क ⿻ 1ิ80

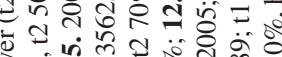
बिं

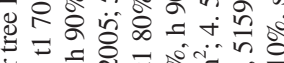

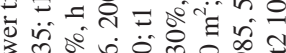

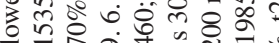

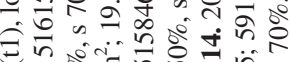

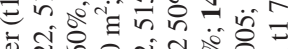

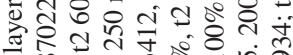
u ir $\forall \ddot{0} \ddot{0} \ddot{0}=\dot{0}$

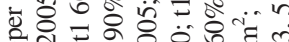

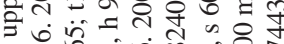

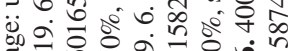
o응

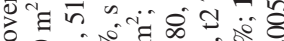
co

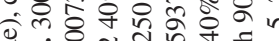

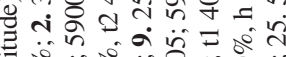

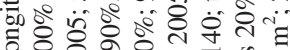
응ㅇㅇㅇㅇำ

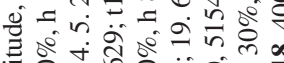

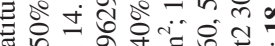
in w so o ñ

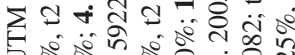
ट⿺辶。 औ

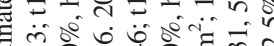

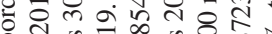

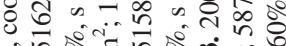

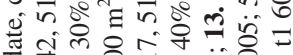

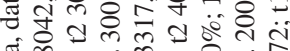

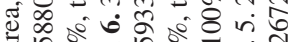
๙n

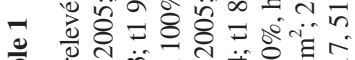

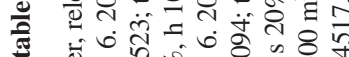
\& 20000

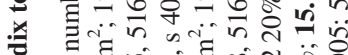

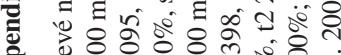

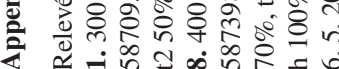




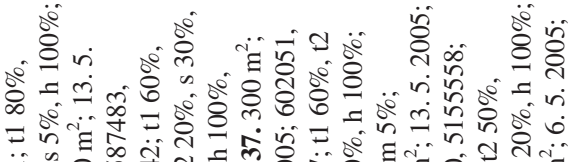
$\ddot{\bar{\sigma}}$ a 各

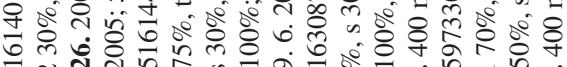

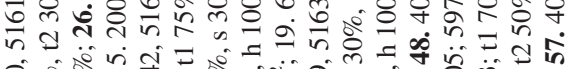

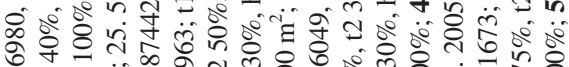
of J й

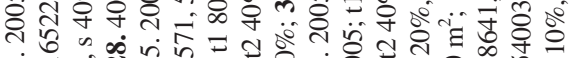

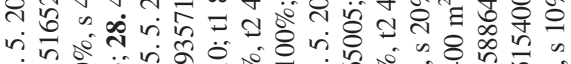

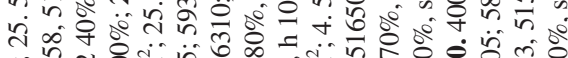

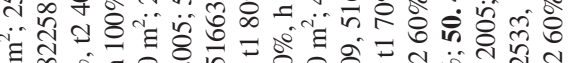

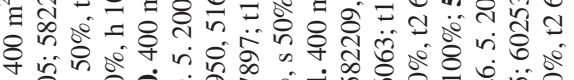

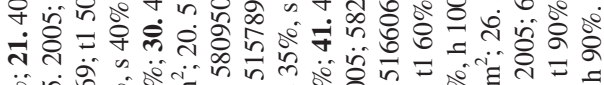

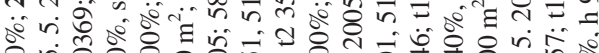

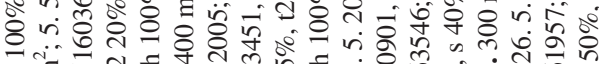
I

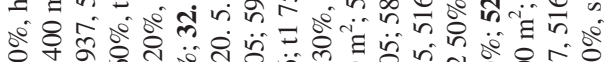

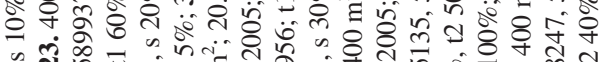
๓

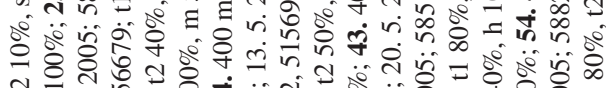

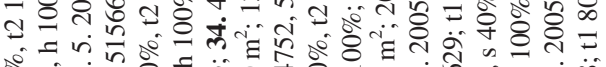

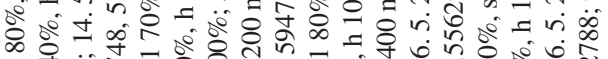

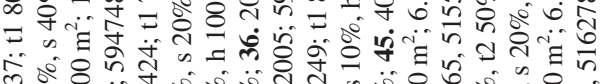

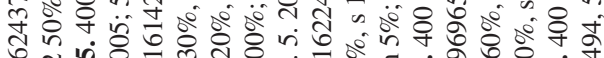

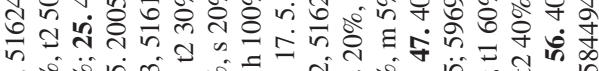

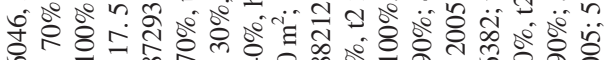
然

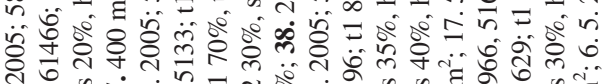

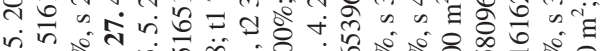
+

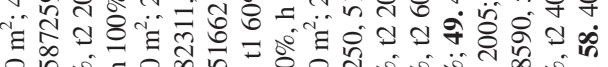

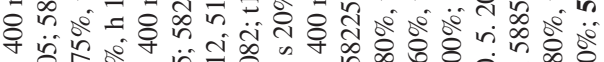

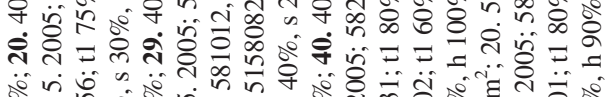

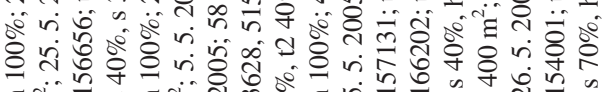

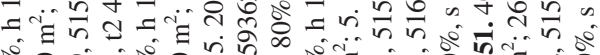

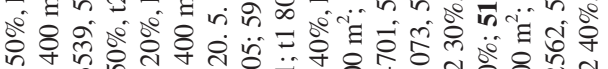

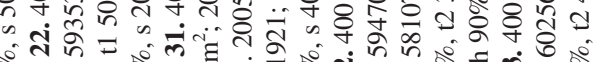

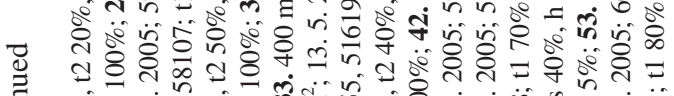
o든

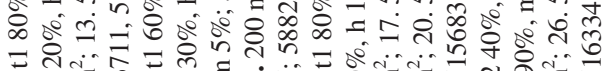

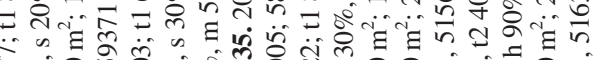

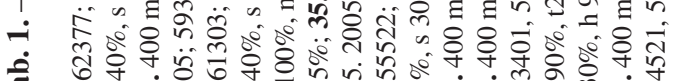

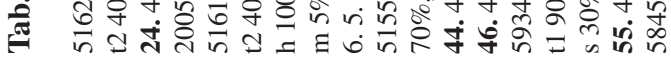

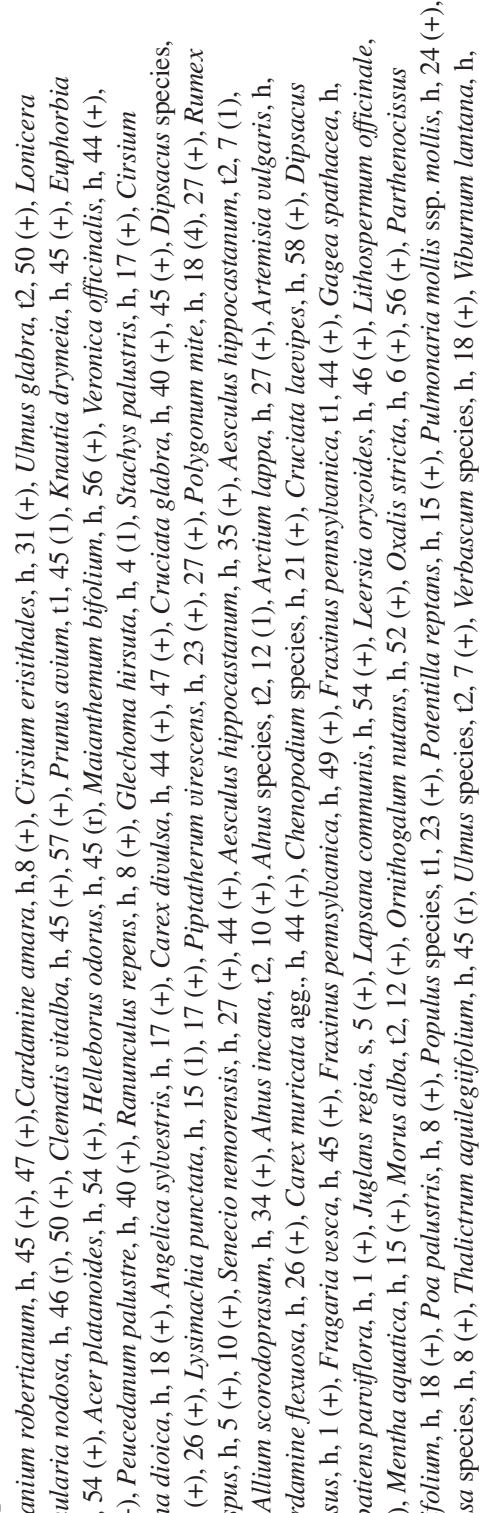

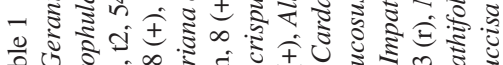

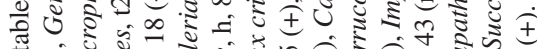

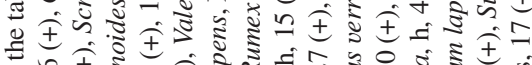

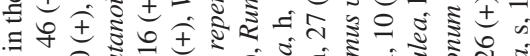

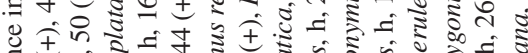

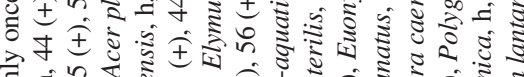

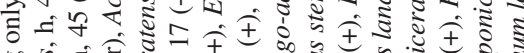

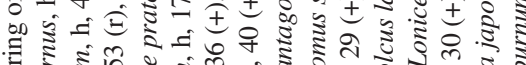

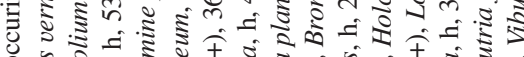

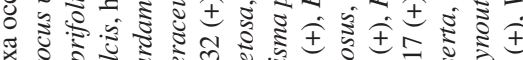

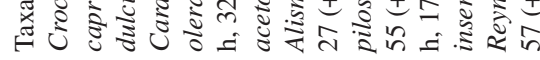


KOŠIR P., ČARNI A., MARINŠEK A., ŠILC U.

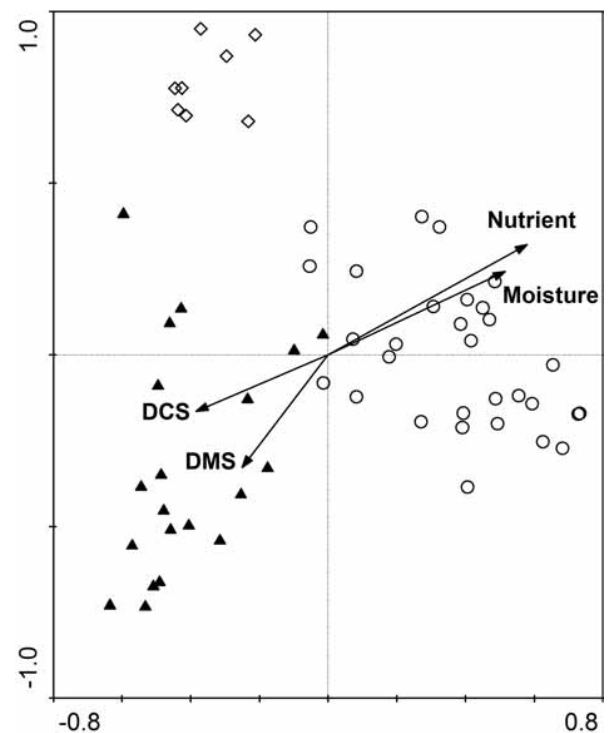

Fig. 2. Passive projection of Ellenberg indicator values and values of DCS and DMS onto the PCA diagram of relevés and species of flooded sites of the Mura River. Only indicator values with the highest correlations with the first two PCA axes are shown. The highest correlations with the first axis are shown by the indicator values for nutrients $(0.579)$, moisture $(0.515)$ and DCS (-0.384), with the second axis the values for DMS (-0.328). Legend: O Salix alba and Populus nigra stands (Salicetum albae Issler 1926), $\diamond$ Fraxinus angustifolia subsp. oxycarpa stands (Fraxino-Ulmetum effusae Slavnić 1952 allietosum ursini subass. nova hoc loco), Quercus robur and Carpinus betulus stands (Fraxino-Ulmetum effusae Slavnić 1952 quercetosum robori subass. nova hoc loco)
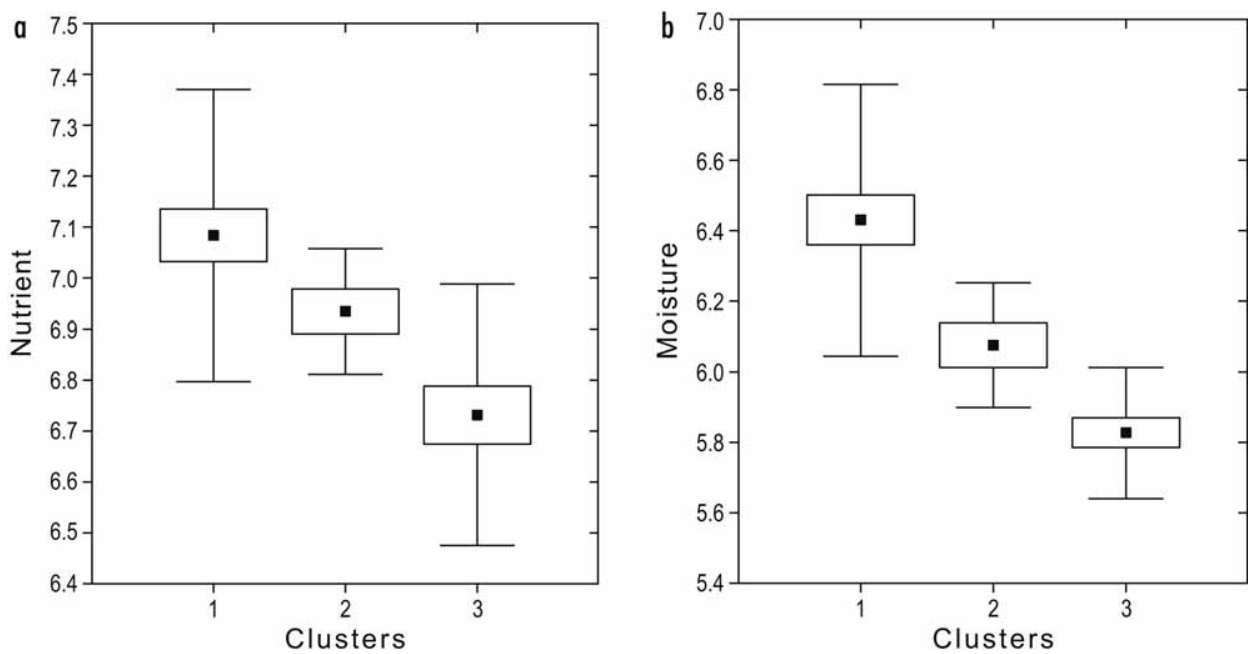

Fig. 3. Mean, standard error (box) and standard deviation (whiskers) of Ellenberg indicator values for nutrients (a) and moisture (b) of the three communities of the flooded forests. Communities (clusters) are numbered as in Fig.1. 

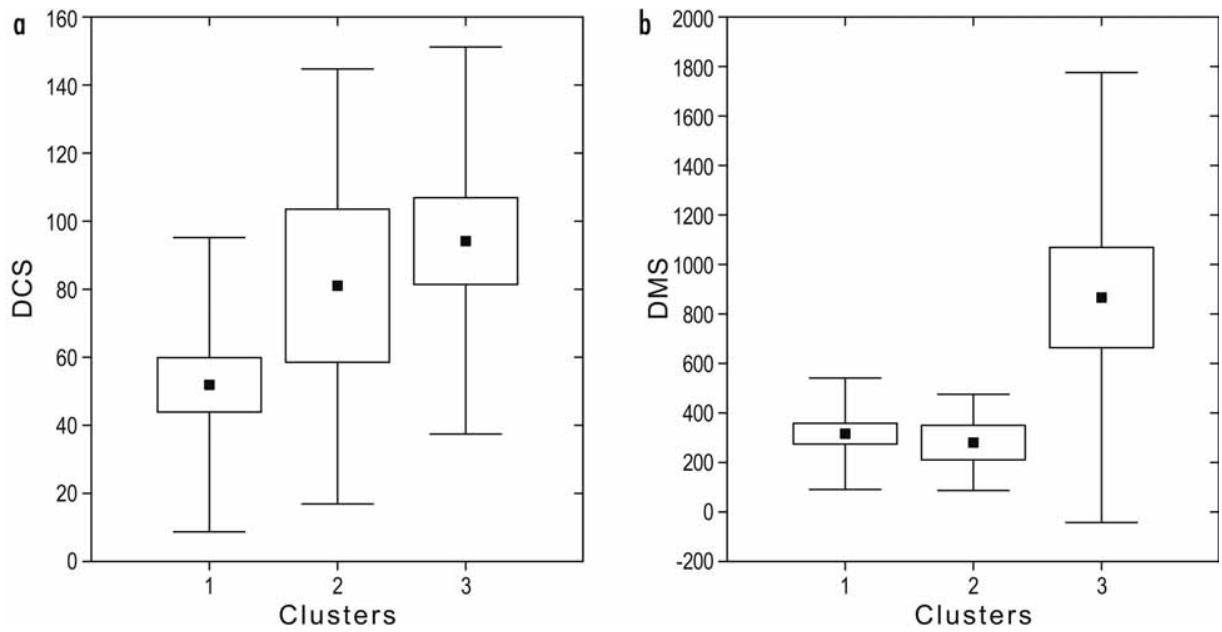

Fig. 4. Mean, standard error (box) and standard deviation (whiskers) of distance from the closest stream (DCS) (a) and distance from the main stream (DMS) (b) of the three clusters. Clusters are numbered as in Fig. 1.

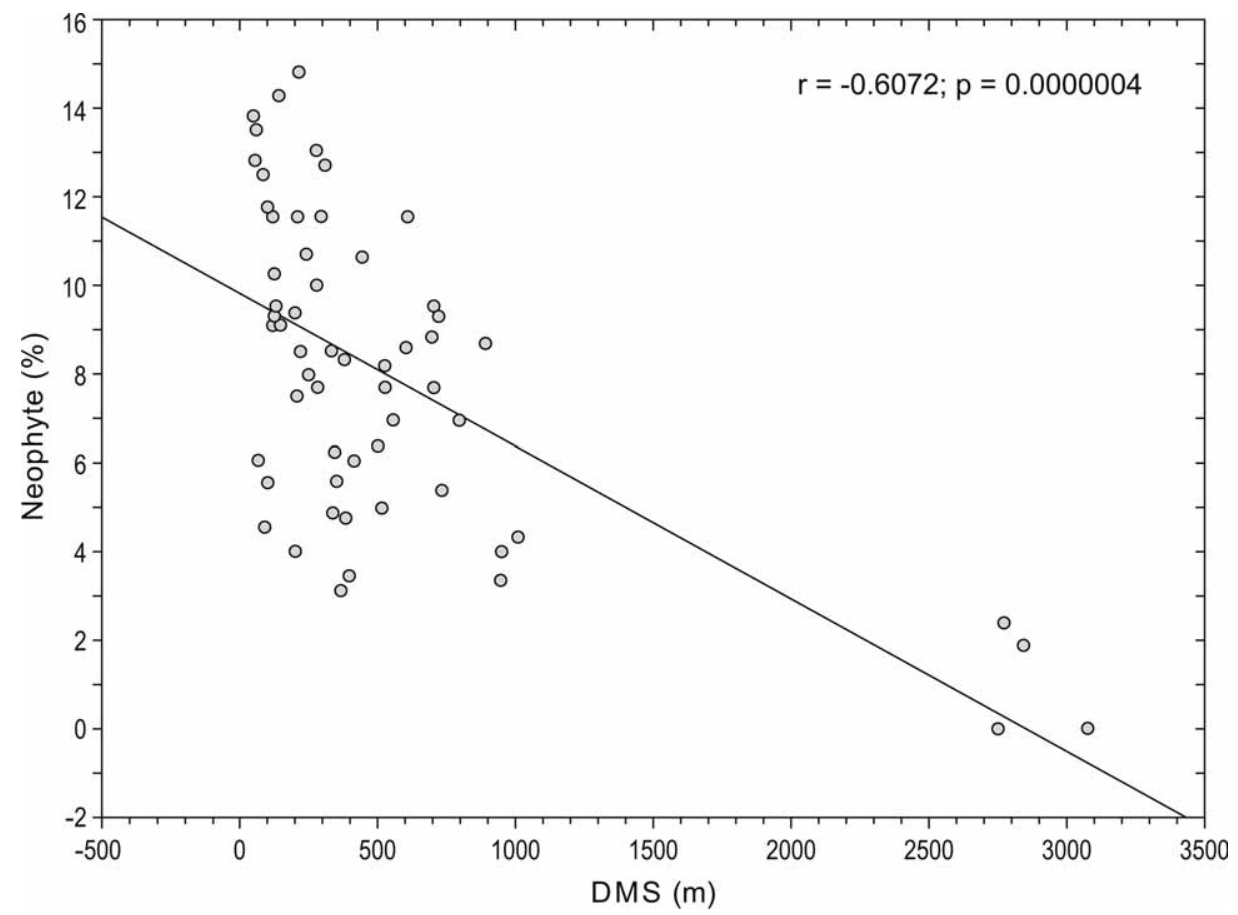

Fig. 5. Relation between the proportion of neophytes and increasing distance from the main stream (DMS).

In the case of life forms, correlation with DCS was very highly significant only in the case of therophytes (Fig. 6). Correlation with DMS was not significant in any case of life form. 
KoŠIR P., ČARNI A., MARINŠEK A., ŠILC U.

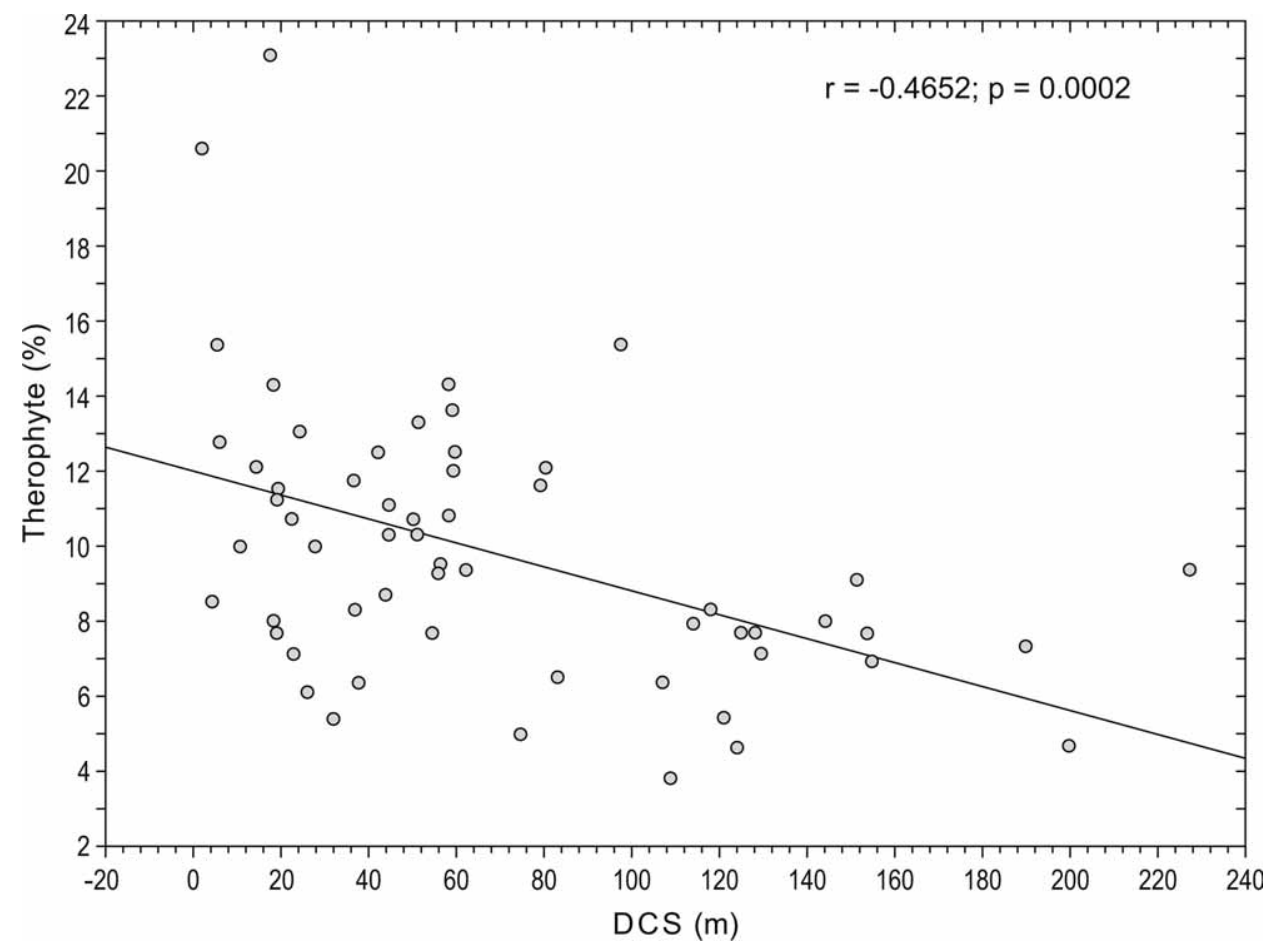

Fig. 6. Relation between the proportion of therophytes and increasing distance from the closest stream (DCS).

Correlations of ecological strategists and DCS and DMS was calculated with regression analysis. No analysis show statistical significant correlation.

In all three clusters hemicryptophytes represent the biggest proportion of species, geophytes and phanerophytes follow. Therophytes represent the smallest proportion of species in the relevés of three clusters (Tab. 2).

Tab. 2. Mean value of the share (\%) of life forms with standard deviations (SD) of the three clusters.

\begin{tabular}{lccc}
\hline life form & cluster 1 & cluster 2 & cluster 3 \\
\hline Hemicryptophytes & $37.6 \pm 8.96$ & $48.37 \pm 6.88$ & $41.67 \pm 6.87$ \\
Geophytes & $22.16 \pm 7.74$ & $21.62 \pm 2.94$ & $22.79 \pm 6.05$ \\
Phanerophytes & $20.95 \pm 5.4$ & $13.17 \pm 3.61$ & $20.47 \pm 5.62$ \\
Therophytes & $11.8 \pm 3.66$ & $7.68 \pm 1.57$ & $7.55 \pm 2.48$ \\
\hline
\end{tabular}

All three clusters consist of a mixture of different strategists (C-S-R, C, C-S, C-R and R). The proportions of CSR and C species were the highest in all three clusters (Tab. 3).

Species response curves fitted using HOF models (Fig. 7) describe the relationships among the main tree species of flooded forests of the Mura River and environmental variables DCS (Fig. 7a) and DMS (Fig. 7b). 
Tab. 3. Mean value of the share (\%) of C-S-R strategies with standard deviations (SD) of three clusters.

\begin{tabular}{lccc}
\hline strategy type & cluster 1 & cluster 2 & cluster 3 \\
\hline C-S-R & $36.25 \pm 8.07$ & $41.09 \pm 3.79$ & $41.14 \pm 5.5$ \\
C & $33.54 \pm 6.87$ & $27.07 \pm 3.18$ & $31.28 \pm 5.35$ \\
C-S & $10.8 \pm 5.15$ & $13.66 \pm 3.98$ & $11.81 \pm 2.28$ \\
C-R & $9.81 \pm 4.06$ & $6.81 \pm 1.55$ & $6.82 \pm 2.45$ \\
R & $4.25 \pm 1.5$ & $3.71 \pm 1.59$ & $3.67 \pm 2.22$ \\
\hline
\end{tabular}
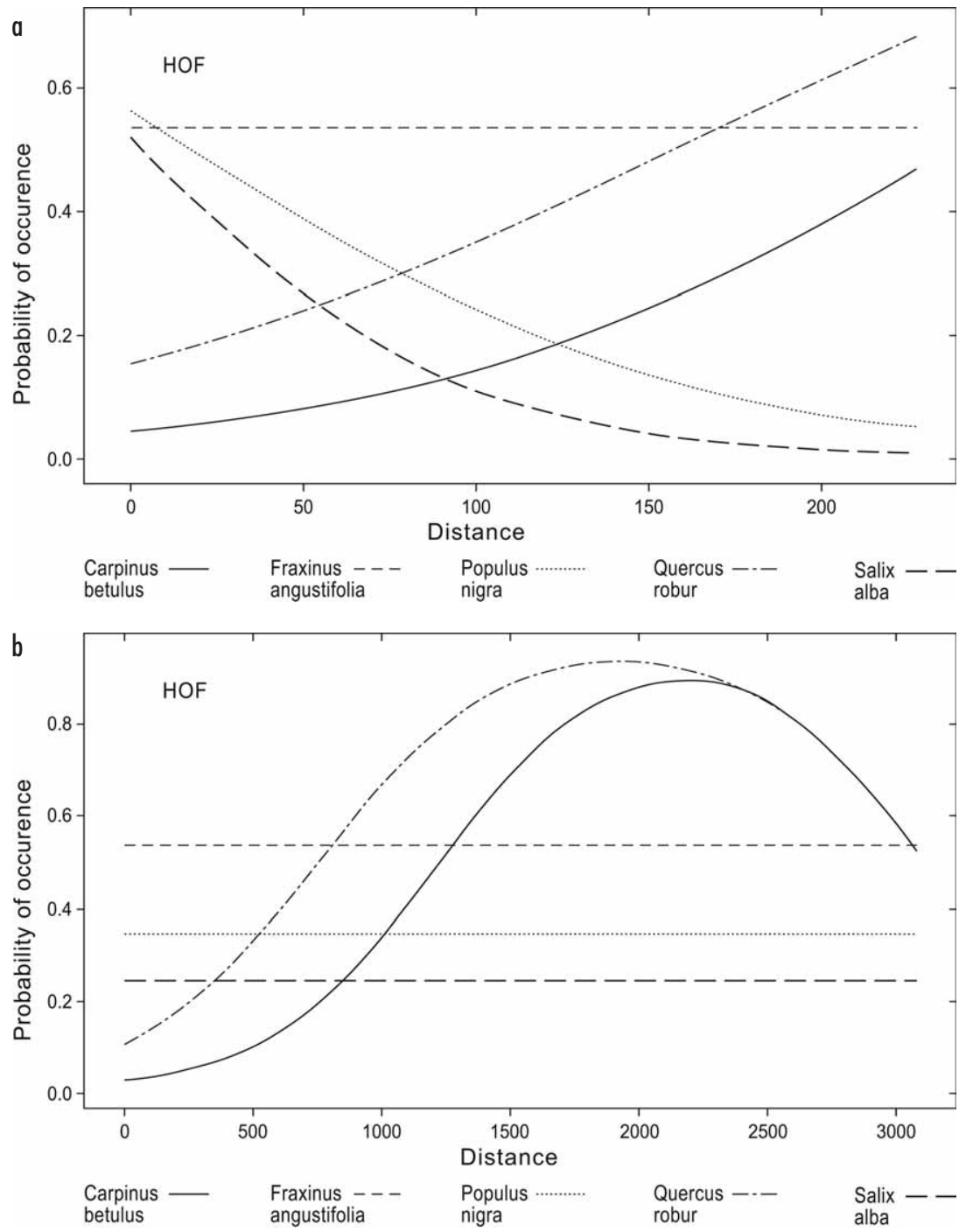

Fig. 7. Probability of occurrence of the main tree species of the area of the Mura River on the gradients of DCS (a) and DMS (b), modelled with the Huisman-Olff-Fresco models. Only species occurrences in the tree layer were considered for modelling. 
Carpinus betulus and Quercus robur respond to both DCS and DMS. They are found in areas distant from streams. Fraxinus angustifolia subsp. oxycarpa does not respond to either DCS or DMS. Salix alba and Populus nigra respond only to DCS and do not respond to DMS. Their response is the opposite of the response of Carpinus betulus and Quercus robur as they are found close to the stream.

\section{Discussion}

\section{Zonation of plant communities and ecological gradients}

The three forest vegetation types that appear on river banks were detected with numerical analysis (Fig. 1). The main ecological gradients that influence the species composition of these forests are nutrients and moisture, and they are negatively correlated with distance from the stream (DCS, DMS) (Fig.2). Moisture- and nutrient-rich plots are closer to the stream. Distance from the first closest stream (DCS) shows bigger correlation to species composition than DMS and it is the underlying gradient of vegetation zonation, which can be also seen from the DCS values of the three forest vegetation types (Fig. 4a). Three forest vegetation types are also ecologically delimited (Fig. 3a,b) as there is a distinction between the ecological values of the three groups of relevés. The values of relative elevation of the plots were much equalized, (as forests in depressions - floodplain swamp forests - were not included), and therefore do not influence species composition.

The three communities have been classified into syntaxa, as follows.

Syntaxonomical scheme:

Salicetea purpurae Moor 1958

Salicetalia purpurae Moor 1958

Salicion albae Soó 1930

Salicetum albae Issler 1926

Querco-Fagetea Br.-B1. et Vlieger 1937

Fagetalia sylvaticae Pawlowski in Pawlowski et al. 1928

Alnion incanae Lüdi 1921

Fraxino-Ulmetum effusae Slavnić 1952 subass. allietosum ursini subass. nova hoc loco Holotypus: relevé number 31 in Tab. 1 holotypus hoc loco

Fraxino-Ulmetum effusae Slavnić 1952 subass. quercetosum robori subass. nova hoc loco Holotypus: relevé number 48 in Tab. 1 holotypus hoc loco

In the central part of Europe along big rivers the hardwood association Querco-Ulmetum minoris Issler 1926 (syn. Fraxino-Ulmetum Tx. ex Oberd. 1953) is distinguished by the dominant species Quercus robur, Ulmus minor/laevis, Fraxinus excelsior. In central eastern and south eastern Europe a hardwood association with different Fraxinus species Fraxinus angustifolia subsp. oxycarpa (Fraxino-Ulmetum effusae Slavnić 1952 (syn. Fraxino pannonicae-Ulmetum Soó 1936 corr. 1963)) is the one that occupies the highest positions in floodplain areas along large rivers (WILLNER and GRABHERR 2007, NEUHÄUSLOVÁ et al. 2001, BORHIDI and KEVEY 1996, VICHEREK et al. 2000, VuKELIĆ and BARIČEVIĆ 2004, 2005, RAUŠ 1976, 1992, SLAVNIĆ 1952). That association was first correctly described by Slavnić in 1952 in the floodplain area of Vojvodina (Serbia) along rivers Drava and 
Danube. The reference of SLAVNIĆ (1952) was overlooked by most European researchers who recognized the name Fraxino pannonicae-Ulmetum Soó 1936 corr. 1963 given by Soó (1963) as the correct one.

\section{Description of the syntaxa (Tab. 1, Fig. 3a, b)}

\section{Salicetum albae Issler 1926}

This community occurs along streams, on floodplains and along gravel pits. Along the Mura the white willow (Salix alba) and poplar tree (Populus nigra) form a relatively wide belt of riparian vegetation. These tree species dominate the stands and are also diagnostic species of the association. In the tree layer there are also Alnus glutinosa, Salix fragilis, Ulmus laevis, Fraxinus angustifolia subsp. oxycarpa, Prunus padus and Robinia pseudacacia. The stands are often inundated and the ground water is high. The soil is structureless. Sedimentation is the result of inundation and alluvium deposits and its layers are clearly defined. Diagnostic species (Tab. 1) such as Impatiens glandulifera, Agrostis stolonifera, Elymus caninus, Urtica dioica etc. indicate moist and nutrient-rich, regularly disturbed sites. The large surfaces of the sites of this community were reclaimed in the past and planted with different cultivars of hybrid poplar and alder. The association is widely accepted and described all over Europe.

\section{Fraxino-Ulmetum effusae Slavnić 1952}

The community occurs in a wide belt along the Mura above the belt formed by white willow forests. In the area of Mura river we detected two subassociations of this association (subass. allietosum ursini and subass. quercetosum robori);

Fraxino-Ulmetum effusae Slavnić 1952 subass. allietosum ursini subass. nova. It occurs fragmentarily on finely structured alluvial soil. The sites are only occasionally flooded. The community is confined to the association Salicetum albae. In the tree layer species Fraxinus angustifolia subsp. oxycarpa dominates the stands, while Ulmus laevis, Robinia pseudacacia and Prunus padus also frequently occur. The diagnostic species are characteristic for moist, fresh, nutrient rich sites: Geranium phaeum, Allium ursinum (dominates the herb layer), Festuca gigantea, etc. In the vegetation map of forest communities of the area of Murska Sobota (ČARNi et al. 2008) forests of this subassociation were treated as a variant of Fraxino-Ulmetum effusae Slavnić 1952 var. Prunus padus Vukelić et Baričević 2004.

Fraxino-Ulmetum effusae Slavnić 1952 subass. quercetosum robori subass. nova. In terms of development, this forest type is the most mature and stable in the inundated region, it is the least nutrient rich and the least moist of the three vegetation types (Fig. 3). The dominant tree species in the tree layer is Quercus robur, sometimes also Carpinus betulus, Fraxinus angustifolia subsp. oxycarpa, Robinia pseudacacia and Ulmus laevis. The group of diagnostic species is large, and most species are of ordo Fagetalia (alliance Alnion incanae) and classes Rhamno-Prunetea and Galio-Urticetea. In the vegetation map of forest communities of the area of Murska Sobota (ČARNI et al. 2008) forests of this subassociation were treated as the association Genisto elatae-Quercetum roboris Horvat 1938. Later on, recent analysis showed that this vegetation type was more related to the association Fraxino-Ulmetum than to the association Genisto elatae-Quercetum. SLAVNIĆ (1952) was among the first to point out that the community Fraxino-Ulmetum displays a significant floristic affiliation with the Slavonian forest of pedunculate oak Genisto elatae- 
-Quercetum roboris; however these are two separate systematic units. The community Fraxino-Ulmetum effusae inhabits the highest position of floodplain areas along large rivers, all these areas being exposed to periodical flooding. On the other hand, the community of Genisto elatae-Quercetum occurs in swamps along boggy backwaters, where mollic gleysol is formed (VuKELIĆ and BARIČEVIĆ 2004).

Both the above described subassociations of association Fraxino-Ulmetum effusae correspond well to forests along the upper course of the river Drava (around Varaždin) in Croatia near to Slovenia described by VuKELIĆ and BARIČEVIĆ (2004) as Fraxino-Ulmetum variant Prunus padus (drier variant). As the difference between the variant Prunus padus and variant typicum (more humid variant along the Danube River and lower part of the Sava River) described by the same authors, is significant, we propose a description of subassociations.

Zonation of forest vegetation can also be evidenced in a response curve of the main edifiers of plant communities (Fig. 7a) on the gradient of DCS. Salix alba and Populus nigra, edifiers of association Salicetum albae, are found close to streams and their occurrence decreases with the distance from the stream. The probability of occurrence for the tree species Quercus robur and Carpinus betulus, edifiers of the variant Fraxino-Ulmetum subass. quercetosum robori, increases with distance from the stream. The tree species Fraxinus angustifolia does not respond to DCS, its probability of occurrence is equalized on the gradient of distances, and therefore gets a chance to become dominant in stands in the middle of the distance gradient (Fraxino-Ulmetum subass. allietosum ursini), where the occurrence of Salix and Populus falls and the increasing occurrence of Quercus and Carpinus is still low. Response curve of main edifiers of plant communities in the gradient of DMS on the other hand proved the already established fact that DMS is not an underlying gradient for the zonation of forest vegetation.

\section{Distribution of plant functional types along stream distance gradient}

The group of life forms is a good indicator of disturbance. Short-living species (like therophytes) are favoured by continual disturbance, therefore cover value of therophytes is higher in flooded stand compared to unflooded stands. Long-living species (geophytes, phanerophytes) on the other hand, benefit from the interruption of inundation or from long habitat continuity (GLAESER and WULF 2009). In our case too, the proportion of therophytes in the relevés close to the stream is bigger and decreases with distance from it (Fig. 6). That is because the stands close to the stream are more disturbed by floods, deposition and removal of nutrient material. Other life forms show no statistical significant correlation with DCS as has been already found out also for some other plant communities along the moisture gradient (ZELNIK and ČARNI 2008).

Riparian habitats are considered to be particularly prone to invasion by alien plant species (TICKNER et al. 2001). The expansion of neophytes (alien species introduced to the region after the year 1500 A.D.) in river-floodplain systems characterized the 20th century as human alterations to these systems, such as channel modifications, flow regulation, and floodplain drainage, intensified (SCHNITZLER et al. 2007, TABACCHI et al. 1996). Many alien species are typically wetland species (ZEDLER and KERCHER 2004, SKAÁLOVA and PYŠEK 2009), and some of them have also high nutrient demands (SCHNITZLER et al. 2007). Close to the river the abundant supply of water and the high nutrient content of freshly deposited 
sediments combine with the typically plentiful light availability to promote the successful germination and establishment of alien species (SANCHEZ-PEREZ et al. 1993, SchNitzLER et al. 2003).

As we tested the proportion of neophytes in the stands and their correlation to DCS and DMS, surprisingly there were no significant correlations with DCS, but there was a significant correlation with DMS (Fig. 5). This means that bigger occurrence of neophytes is not connected to certain type of vegetation (willow stands because of their community architecture promote light in the understoreys) as has been reported (SCHNITZLER and Aumaitre 2008). Also in the area of Mura the best preserved willow stands are along side streams (and not along the main stream) as vegetation close to main stream is much more affected by different human impacts. A more important factor is the proximity of the main stream alone, which beside promotion of light (there are many open and disturbed areas near the main stream) assures active dispersal of rhizomes or stems (vegetative matter and seeds) deposited during floods and thereby encourages propagation (SCHNITZLER et al. 2007, RicHARDSON et al. 2007). The flow of the main stream is quick and never drains up, in contrast to side streams.

Both groups of species (neophytes and therophytes) are characteristic of disturbed sites. The proportion of therophytes is significantly negatively correlated with the distance from the closest stream (DCS), which can be easily understood and has been observed and explained already by other authors. More surprising is that neophytes do not respond to environmental factors in the same way as therophytes. A proportion of neophytes does not correlate with the same distance - distance from the closest stream (DCS), but with distance from the main stream (DMS). It seems that for establishment of neophytes, the propagation assured with the flow of the main stream is one of the most important factors beside disturbance itself.

Strong correlations of ecological strategy and moisture gradient have already been detected for some other vegetation types (ZELNIK and ČARNI 2008, TURNER et al. 2004, GLAESER and WULF 2009). Relative elevation and distance from main channel, as indicators of flooding regime, were reported to be consistently important in predicting occurrence, community composition and abundance of species (TURNER et al. 2004, MENGES and WALLER 1983). In our case the distribution of plant ecological strategies indicates similar habitat conditions along transecst from the streams, as there is no statistical significant correlation of plant ecological strategies with DMS and DCS. All relevés were made inside the area of frequent floods (inside dikes) on quite equalized elevations. In our study all three types of vegetation show similar proportions of plant ecological strategies in their compositions.

\section{Conclusion}

The present study contributes basic data on the floristic composition and structure of floodplain forests of Mura river. The zonation of floodplain forests is connected to distance from the closest stream (DCS) and not from the main stream (DMS). Distance from the closest stream influences species distribution through ecological gradients of moisture and nutrient. Three types of forests have been detected along these gradients. The proportion of therophytes is significantly negatively correlated with the distance from the closest stream and the proportion of neophytes is significantly negatively correlated with distance from the 
main stream. The correlation of proportion of neophytes with DMS can be explained by the importance of their effective propagation ensured by flow of the main stream.

\section{Acknowledgements}

Our study was supported by the Ministry of Agriculture, Forestry and Food and Ministry of Higher education, Science and Technology. It was carried out as part of a project V-40983: Ecological circumstances as basis for forest economy and also as part of a research programme P1-0236: Gradients and Biodiversity.

\section{References}

ACCETTO, M., 1994: Moor and flooded forests. Design of ecosystems division (in Slovenian). Oddelek za Biologijo, Biotehniška fakulteta, Ljubljana.

Borhidi, A., Kevey, B., 1996: An annotated checklist of the Hungarian plant communities. In: BoRHIDI, A. (ed.), Critical revision of the Hungarian plant communities, 95-138. Janus Pannonius University, Pécs.

Braun-Blanquet, J., 1964: Pflanzensoziologie. Grundzüge der Vegetationskunde. Springer, Wien.

ČArni, A., KoŠIR, P., MARINČEK, L., MARINŠEK, A., ŠILC, U., ZElniK, I., 2008: Commentary to the vegetation map of forest communities of Slovenia in scale 1:50.000 - section Murska Sobota. Pomurska akademsko znanstvena unija (PAZU), Murska Sobota.

DAKSKOBleR, I., ŠILC, U., ČUŠIN, B., 2004: Riverine forests in the Upper Soča valley (The Julian Alps, western Slovenia). Hacquetia 3, 51-80.

Deiller, A.-F., Walter, J.-M. N., TrÉMOlieres, M., 2001: Effects of flood interruption on species richness, diversity and floristic composition of woody regeneration in the upper Rhine alluvial hardwood forest. Regulated Rivers: Research and Management 17, 393-405.

Glaeser, J., Wulf, M., 2009: Effects of water regime and habitat continuity on the plant species composition of floodplain forests. Journal of Vegetation Science 20, 37-48.

Glavać, V., 1975: Das Pruno-Fraxinetum Oberdorfer 53 in Nordwestkroatien. Beiträge zu naturkundlichen Forschung in Südwestdeutschland-DT1 35, 95-101.

GlobeVnik, L., Mikoš, M., 2009: Boundary conditions of morfodynamic processes in the Mura River in Slovenia. Catena 79, 265-276.

GORŠAK, B., BAKAN, B., 2003: Mura nature park (in Slovenian). Proteus 7, 311-322.

GRIME, J. P., 1979: Plant strategies and vegetation processes. Wiley, Chichester.

HoRvat, I., GLAVAČ, V., Ellenberg, H., 1974: Vegetation Südosteuropas. Geobotanica selecta 10. Gustav Fischer Verlag, Stuttgart.

Hennekens, S. M., SchaminéE, J. H. J., 2001: TURBOVEG, a comprehensive data base management system for vegetation data. Journal of Vegetation Science 12, 589-591.

Huisman, J., OlfF, H., Fresco, L. F. M., 1993: A hierarchical set of models for species response analysis. Journal of Vegetation Science 4, 47-58.

Kevey, B., 2008: Forest associations of Hungary (in Hungarian). Tilia 14, 1-489. 
Klimo, E., Hager, H., 2001: Executive summary. In: Klimo, E., Hager, H. (eds.), The floodplain forests in Europe. Current situation and perspectives, 7-11. European Forest Institute Research report 10, Brill, Leiden.

Klimo, E., Hager, H., Matič, S., Anič, I., KulhavÝ, J. (eds), 2008: Floodplain forests of temperate zone of Europe. Lesnicka prace, s.r.o., Kostelec nad Černými lesy.

Klotz, S., KüHN, I., DuRKA, W., 2002: BIOLFLOR: Eine Datenbank mit biologisch-ökologischen Merkmalen zur Flora von Deutschland. Schriftenreiche für Vegetationskunde $38,1-334$.

Machar, I., 2001: Floodplain forest in Hornomoravský úval, Czech Republic. In: KLIMO, E., Hager, H. (eds.), The floodplain forests in Europe. Current situation and perspectives, 37-50. European Forest Institute Research Report 10, Brill, Leiden.

McCunE, B., MeFFoRd, M. J., 2005. PC-ORD, Multivariate analysis of ecological data, Version 5 for Windows edition. MjM Software Design, Gleneden Beach.

Menges, E. S., Waller, D. M., 1983: Plant strategies to elevation and light in floodplain herbs. The American Naturalist 122, 454-473.

Mitsch, W. J., GosselinK, J. G., 2000: Wetlands, 3. John Wiley, New York.

Müller, T., 1992: Verband: Alno-Ulmion. In: OBERDORFER, E. (ed.), Süddeutsche Pflanzengesellschaften. Wälder und Gebüsche, 173-192. Gustav Fischer Verlag, Jena.

Nemesszeghy, L., 1986: Black alder in Prekmurje (in Slovenian). Pomurska založba, Murska Sobota.

NeuhäuslovÁ, Z., Moravec, J., Chytrý, M., LožEK, V., RybníčEK, K., RybníčEKovÁ, E., Husová, M., Grulich, V., Jeník, J., SÁdlo, J., JiRÁseK, J., KolbeK, J., Wild, J., 2001: Potential natural vegetation of the Czech Republic. Braun-Blanquetia 30, 1-80.

Oksanen, J., Minchin, P. R., 2002: Continuum theory revisited: what shape are species responses along ecological gradients? Ecological Modelling 157, 119-129.

PAal, J., RAnNiK, R., Jeletsky, E.-M., Prieditis, N., 2007: Floodplain forests in Estonia: Typological diversity and growth conditions. Folia Geobotanica 42, 383-400.

Petrinec, V., 1999: Vegetationsmonographie von Šturmovci (NO-Slowenien). Diplomarbeit, Universität Wien.

Poldini, L., Vidali, M., Ganis, P. 2011: Riparian Salix alba: Scrubs of the Po lowland (N-Italy) from an European perspective. Plant Biosystems 145 (Suppl. 1), 132-147.

RAUš, Đ., 1976: Vegetation of marshlands forests in Podunavlje between Alajmaš and Ilok (in Croatian). Annales pro Experimentis Foresticis 19, 5-75.

RAUŠ, Đ., 1992: Vegetation of marshlands forests along the river Drava between Varaždin and Osijek with particular attention paid to the Varaždin forests along the river (in Croatian). Annales pro Experimentis Foresticis 28, 245-256.

Richardson, D. M., Holmes, P., Esler, K. J., Galatowitsch, S. M., Stromberg, J. C., Kirkman, S. P., PyšEK, P., HobBS, R. J. 2007: Riparian vegetation: degradation, alien plant invasions, and restoration prospects. Diversity and Distribution 13, 126-139.

Sanchez-Perez, J. M., Trémolières, M., Schnitzler, A., Badre, B., CArbiener, R., 1993: Nutrient content in alluvial soils submitted to flooding in the Rhine alluvial deciduous forest. Acta Oecologica 14, 371-387. 
KoŠIR P., ČARNI A., MARINŠEK A., ŠILC U.

SLAVNIĆ, Ž., 1952: Lowland forests of Vojvodina (in Sebian). Zbornik Matice Srpske 2, $17-38$.

SCHNITZLER, A., 1994: European alluvial hardwood forests of large floodplains. Journal of Biogeography 21, 605-623.

Schnitzler, A., Gafta, D., Cornier, T., 2003: Concepts architecturaux et particularités écosystémiques des ripisylves. In: Piégay, H., Pautou, G., Ruffinoni, C.(eds.), Les forêts riveraines des cours deau, écologie, fonctions et gestions, 30-45. Institut pour le developpement forestier, Town?

Schnitzler, A., Hale, B. W., Alsum, E. M., 2007: Examing native and exotic species diversity in European riparian forests. Biological Conservation 138, 146-158.

Schnitzler, A., Aumaitre, D., 2008: Invasiveness and Invisibility After Change Sin Land Uses. Proceedings 12 World Lake Conférence, Jaipur, 1046-1050.

SkÁlova, H., PYŠEK, P., 2009: Germination and establishement of invasive and native Impatiens species in species-specific microsites. In: PYšEK, P., PERGL, J. (eds.), Biological Invasions: towards a Synthesis. Neobiota 8, 101-109.

Soó, R., 1963: Systematische Übersicht der pannonischen Pflanzengesellschaften, 6. Die Gebirgswälder 2. Acta Botanica Hungarica 9, 123-150.

STATSOFT, inc., 2007: STATISTICA (data analysis software system), version 8.0. www. statsoft.com.

ŠILC, U., 2003: Vegetation of the class Salicetea purpureae in Dolenjska (SE Slovenia). Fitosociologia 40, 3-27.

Tabacchi, E., Planty-Tabacchi, A.-M., Salinas, M. J., Décamps, H., 1996: Landscape structure and diversity in riparian plant communities: a longitudinal comparative study. Regulated rivers: Research \& Management 12, 367-390.

TER BraAK, J. F. C., ŠMilauer, P., 2002: CANOCO Reference Manual and CanoDraw for Windows Userž s Guide. Software for Canonical Community Ordination (version 4.5). Microcomputer Power, Ithaca.

TICHÝ, L., 2002: JUICE, software for vegetation classification. Journal of Vegetation Science 13, 451-453.

TiChÝ, L., CHYTRÝ, M., 2006: Statistical determination of diagnostic species for site groups of unequal size. Journal of Vegetation Science 17, 809-818.

Tickner, D. P., Angold, P. G., Gurnell, A. M., Mountford, J. O., 2001: Riparian plant invasions: hydrogeomorphological control and ecological impacts. Progress in Physical Geography 25, 22-52.

Turner, M. G., Gergel, S. E., Dixon, M. D., Miller, J. R., 2004: Distribution and abundance of trees in floodplain forests of the Wisconsin River: Environmental influences at different scales. Journal of Vegetation Science 15, 729-738.

Tutin, T. G., Heywood, V. H., Burges, N. A., Moore, D. M., Valentine, D. H., Walters, S. M., WebB, D. A. (eds.) 1964-1980: Flora Europaea, 1-5. Cambridge University Press, Cambridge.

Vicherek, J., Antonín, V., Danihelka, J., Grulich, V., Gruna, B., Hradílek, Z., RehoReK, V., Šumberová, K., VAmpola, P., VÁGner, A., 2000: Flora and vegetation at the confluence of the Morava and Dyje rivers (in Czech). Masarykova Univerzita v Brne, Brno. 
VUKELIĆ, J., BARIČEVIĆ, D., 2004: The association of spreading elm and narrow-leaved ash (Fraxino-Ulmetum laevis Slav. 1952) in floodplain forests of the Podravina and Podunavlje. Hacquetia 3, 49-60.

Vukelić, J., BARIČEVIĆ, D., 2005: Forest vegetation of flooded regions (in Croatian). In: Vukelić, J., Prpić, B., Kajba, B., Matić, S., Vratarić, P., Glavaš, M., Jakovac, H., Floodplain forests in Croatia (in Croatian). Akademija šumarskih znanosti, Zagreb.

Willner, W., GrabHERr, G., 2007: Die Wälder und Gebüsche Österreichs. Spektrum, Akademischer Verlag.

ZEDLER, J. B., KERCHER, S., 2004: Causes and consequences of invasive plants in wetlands: oppurtunists and outcomes. Critical Reviews in Plant Sciences 23, 431-452.

ZelenÝ, D., TichÝ, L., 2007: Species response curves in JUICE. Retrieved September 9, 2009, from http://sci.muni.cz/botany/zeleny/hof.php

ZELNIK, I., ČARNI, A., 2008: Distribution of plant communities, ecological strategy types and diversity along a moisture gradient. Community Ecology 9, 1-9. 